\title{
Using Educational Theory and Moral Psychology to Inform the Teaching of Ethics in Computing
}

\author{
Melissa J. Dark \\ Purdue University \\ Knoy Hall, Room 467 \\ West Lafayette, IN 47907 \\ 765-494-7661 \\ dark@purdue.edu
}

\author{
Jeanne Winstead \\ 6960 South 500 East \\ Lafayette, IN 47905 \\ 765-523-2366 \\ benwin@verizon.net
}

\begin{abstract}
In this paper, we explore the teaching of ethics in computing related fields. The article intends to share ideas on moral development and the nature of morality, specifically as it relates to changes that educators may be trying to elicit within students when teaching ethics. The paper then addresses educational theories that are better suited to enabling moral development with suggestions on how these theories might shape classroom climate and instructional approaches.
\end{abstract}

\section{Categories and Subject Descriptors}

K.4. [Computing Mileux]: Computers and Society. K.7.4 [The Computing Profession]. Professional Ethics.

\section{General Terms}

Legal Aspects.

\section{Keywords}

Ethics, moral development, constructivism, critical theory.

\section{INTRODUCTION}

Teaching ethics in computing is not a new topic [1] [3] [5] [6] [10] [12] [13] [16] [17] [19]. The call for teaching ethics is partially related to the use of computers in society. As computers become more pervasive in society and daily life, issues of information security, such as privacy, ownership, access, and liability, reliability and safety also become more important. As these ethical issues grow in importance, a niche area of computing ethics is arising, specifically information security ethics.

Our experience working with information security and computer science faculty has led us to believe that technical educators are less familiar and sometimes uncomfortable with teaching a topic such as ethics because it is not positivistic in nature. For example, in one discussion, a faculty member noted "A common definition of ethics is "doing what is right when no one is looking".

So,

Permission to make digital or hard copies of all or part of this work for personal or classroom use is granted without fee provided that copies are not made or distributed for profit or commercial advantage and that copies bear this notice and the full citation on the first page. To copy otherwise, or republish, to post on servers or to redistribute to lists, requires prior specific permission and/or a fee.

Information Security Curriculum Development (InfoSecCD) Conference '05, September 23-24, 2005, Kennesaw, GA, USA. Copyright 2005 ACM 1-59593-261-5/05/0009...\$5.00. teach ethics, professional or otherwise, one must first define what is right and what is not right (i.e., define truth) and then address what happens if one does not do what is right, or does what is wrong". We respectfully disagree. We are not of the mind that you can teach right and wrong. Certainly, we have laws that codify right and wrong for a society, but there are many things that are ethically questionable that are not illegal. And, while society might have laws that guide right and wrong, that does not mean that right can be defined as truth and wrong as untruth. So, we decided to write this paper. This is not a "how to" paper; we will not discuss the practice of teaching. Our goal is to put forth abstract concepts, big ideas if you will, that might help educators think differently and/or more deeply about the teaching/learning exchange in the domain of ethics.

\section{CAN WE TEACH MORAL DEVELOPMENT?}

"Teachers and philosophers have long recognized that it is difficult, if not impossible, to 'teach' someone ethics” [13]. Rather, what we are truly trying to accomplish is the much more complicated task of advancing students' sense of moral development and reasoning. Kohlberg's [11] work in moral development posits that there are three levels and six stages of moral development as summarized in Table 1 below.

Table 1. Kohlberg's Stages of Moral Development

\begin{tabular}{|l|l|l|}
\hline Level & Stage & Characteristics \\
\hline $\begin{array}{l}\text { Level 1: } \\
\text { Preconventional }\end{array}$ & $\begin{array}{l}\text { Punishment } \\
\text { and } \\
\text { obedience } \\
\text { orientation }\end{array}$ & $\begin{array}{l}\text { Right action is determined } \\
\text { by the physical } \\
\text { consequences of action } \\
\text { regardless of the human } \\
\text { meaning or value of the } \\
\text { consequences }\end{array}$ \\
\cline { 2 - 3 } & $\begin{array}{l}\text { Instrumental } \\
\text { relativist } \\
\text { orientation }\end{array}$ & $\begin{array}{l}\text { Right action is made up of } \\
\text { that which serves one's own } \\
\text { needs and sometimes the } \\
\text { needs of others }\end{array}$ \\
\hline Level 2: & $\begin{array}{l}\text { Interpersonal } \\
\text { concordance } \\
\text { orientation }\end{array}$ & $\begin{array}{l}\text { Right action is that which } \\
\text { pleases or helps others and is } \\
\text { condoned by them }\end{array}$ \\
\cline { 2 - 3 } & $\begin{array}{l}\text { Law and } \\
\text { order }\end{array}$ & $\begin{array}{l}\text { Right action is that which is } \\
\text { sanctioned by authority, }\end{array}$ \\
\hline
\end{tabular}




\begin{tabular}{|l|l|l|}
\hline & orientation & $\begin{array}{l}\text { rules and maintaining social } \\
\text { order }\end{array}$ \\
\hline $\begin{array}{l}\text { Level 3: Post- } \\
\text { conventional }\end{array}$ & $\begin{array}{l}\text { Social- } \\
\text { contract } \\
\text { legalistic } \\
\text { orientation }\end{array}$ & $\begin{array}{l}\text { Right action is conceived in } \\
\text { terms of general individual } \\
\text { rights and also standards that } \\
\text { have been critically } \\
\text { examined and agreed upon } \\
\text { by the entire society }\end{array}$ \\
\cline { 2 - 3 } & $\begin{array}{l}\text { Universal } \\
\text { ethical } \\
\text { principle } \\
\text { orientation }\end{array}$ & $\begin{array}{l}\text { Right action is that which is } \\
\text { in accord with self-chosen } \\
\text { ethical principles appealing } \\
\text { to logical } \\
\text { comprehensiveness, } \\
\text { universality, and consistency }\end{array}$ \\
\hline
\end{tabular}

Moral development is not analogous to academic achievement and cannot be taught in the same way that facts, concepts, proofs or principles are taught. We believe that the goal of teaching computing ethics is not to teach students what is right and what is wrong; it seems to us to be counterproductive to teach at the conventional level given that our target audience is young adults. Rather, we suggest that the aim should be to create an environment that allows students to safely question and reflect on their moral beliefs relative to their future professions. It is through such questioning and reflection that advancement can occur. Advancements in moral beliefs are internal to the individual and complex in nature in that at least three domains are involved: cognitive, affective, and social.

\section{THE NATURE OF MORALITY}

\subsection{Cognitive Aspects}

The matching of a moral view to one's experiences is in part a cognitive process. As humans develop, they employ cognitive skills, such as identifying and analyzing a problem, applying past learning, gathering new information, organizing and comparing data, analyzing elements and relationships, clarifying and judging alternatives, and summarizing solutions [9]. However, moral development within the individual is about more than cognition. It involves knowing, caring, and acting [2], which is in the affective domain.

\subsection{Affective Aspects}

Affective development is concerned with feelings and emotions; affect can be described by an individual's feelings, emotions, willingness, preferences/dispositions, attitudes, interests, and appreciations. "As affective behaviors move from simple to complex......they become increasingly internalized and integrated with other behaviors (both affective and cognitive) to form complex value systems and behavior patterns" [9].

\subsection{Social Aspects}

Behaviors patterns are intricately linked to socialization, social processes and societies. The domain of social intelligence involves what [7] called critical consciousness, more specifically the ability to see and understand social myths. Social intelligence is also the capacity to recognize the need for social action and respond to that understanding in a personally and socially effective manner.
Against this backdrop of cognitive, moral, and social development, we see that the origins of human morality are "emotions linked to expanding cognitive abilities that make people care about the welfare of others, about cooperation, cheating, and norm following" [8]. If human morality begins with human emotions and socialization, then ongoing moral development "involves a continual process of matching a moral view to one's experience of life in a social world. And experiences of conflict in this process generate movement from structural stage to structural stage” [11].

The spiral of moral development [15] includes moving among the social, the cognitive, and the affective domains, but this does not happen in a predetermined sequence. For purposes of advancing students' moral development, addressing ethics in only one domain or trying to decouple what aspects of change are cognitive versus affective and/or social is naïve.

\section{CHANGES WE ARE TRYING TO ELICIT WITHIN STUDENTS}

As mentioned above, the changes we are trying to elicit within students are developmental changes that are cognitive, affective, and social in nature. However, unless we further define these changes in terms of traits or characteristics that we are looking for, it is difficult to know if students possess them before or after instruction. We formulated the following suggested competencies for the purpose of this paper; we are not implying that this is a complete inventory, rather we hope it is a worthy start.

In ethics education, we are seeking to teach students not to accept authority blindly on the basis of habit and tradition, specifically as it relates to issues of ethics in information security. We are seeking to develop in students the capacity for critical examination of one's own assumptions and tendencies. We are seeking to engender in computing students an ability to step outside of their own skins, and to view themselves from the perspective of an outsider, asking the questions an outsider is likely to ask about the meaning and function of their craft [14]. In doing so, we think it is important to develop in students both a sense of their vulnerabilities and the ability to recognize their own reflection in the experiences of others inside or out of their frame of reference [14]. We want students to understand the impact of computing on the nature of social relationships and to be able to take the perspective of others in the course of contemplating social relationships. We are seeking to develop within students the ability and desire to participate in civil discourse in a manner that focuses on a shared future. We want to develop in students the notion that they are members of what psychologists term a "superordinate group." This size of this superordinate group could range from being a member of a classroom to being a "citizen of the world" [14]. This is more than just grand sentiment. It is one of the keys to "knowing, caring, and acting" that we have referred to earlier (in that people tend to take care of their own) and also to students' spiral of moral development as they try to resolve conflicts between the various groups to whom they owe allegiance. We want to engage students in an enthusiastic understanding of how computing professionals function and contribute to the construction of the superordinate group. Above all, we need to develop within our students a sense of deliberativeness and reflection, because these capacities provide 
the necessary foundation for all of the aforementioned skills and abilities.

The above list merely suggests abilities or proclivities that would indicate that the student is developing morally. Regardless of the particular ability or proclivity, as students change their value system and/or behavior patterns in a way that could be considered developmental, we can expect to see either 1) a change in the general shape, pattern, or organization of their responses, or 2) a newness and/or qualitatively different response as opposed to simply a change in the frequency or intensity of emission of an already patterned response” [11]. Development entails the "emergence of a novel structure of response. A really new kind of experience.......is one that is different in its form or organization, not simply in the element or the information it contains" [11].

Do you, as an educator, think that it is your responsibility to help students develop in this way?

Most educators have beliefs about how learning occurs, and often those beliefs are based on 1) how they learn, and/or 2) how they were taught. These beliefs are often implicit and if you ask a teacher what he/she believes, they may not be able to articulate it. However, these beliefs are powerful and strongly influence teaching practices. Next we will overview different learning theories and focus on two that we think better lend themselves to the domain of ethical development with the hope that our readers will reflect and perhaps rethink their beliefs, which in turn may lead to a change in teaching practices.

\section{BEHAVIORISM AND COGNITIVISM}

Behaviorism posits that all behavior is determined by the environment, either through association or reinforcement. Therefore, the teacher's role is to provide positive reinforcement to the right behaviors and negative reinforcement to wrong behaviors. While behaviorist reinforcement (i.e., grades, recognition in the classroom) is used in education, we firmly believe that a behaviorist approach to moral development is conventional, short sighted, and counterproductive. In contrast, cognitivism is focused on how information is organized, structured, and conceptualized. A key role of the teacher is to provide structure and organization in a manner that helps students assimilate and acquire the information. We believe that cognitive approaches have a place in teaching ethics, but are not sufficient because they focus mainly on intellectual skills without integrating the affective and social domains. Cognitive approaches are primarily used in lectures, the predominant information dissemination method used. Two theoretical frameworks that are more appropriate for engendering moral development are constructivism and critical theory. What we would like to do is spend the remainder of the paper discussing key aspects of these theories in the hope that our readers will reflect and question their beliefs about learning and teaching, especially in the ethical domain.

\section{CONSTRUCTIVISM}

Contrary to cognitivism, a central tenet of constructivist philosophy is that "knowledge is not transmitted, it is constructed" [18]. Constructivism comes in various flavors, such as "individual constructivism," which holds that knowledge is constructed from experience and through the individual's interpretation of that experience [18], "social constructivism," which holds that learning is collaborative in nature with meaning negotiated from multiple perspectives," [18] and contextualism which holds that learning should be "situated" (occur in realistic settings) [18]. Following are several of the guiding principles of constructivism:

1. Learning is a search for meaning, meaning is derived from experience, and experience is the result of continuous active agency. Therefore, learning should start with the issues around which students are actively trying to construct meaning and should provide enough significant opportunities for students to gain experience in a reflective and iterative manner.

2. Meaning requires understanding wholes and their constituent parts. Furthermore, parts must be understood in the context of wholes. The learning process focuses on primary concepts and not isolated facts. Learners should build organizational patterns of association between primary concepts and affiliated parts through experience.

3. Meaning that is derived from experience is powerful because it is fundamentally self-referent; that is to say it is deeply rooted in personal identity and viewing life from the inside out in the context of social systems.

4. In order to teach well, we must understand the mental models that students use to perceive the world and the assumptions they make to support those models.

5. Meaning making is dynamic and full of continuous tension, in fact tension is a necessary part of the process. When an individual must choose between beliefs, ideas, attitudes and behaviors that are contradictory, then the learner will embark on meaningful learning. This tension/discord creates the need for action on the part of the learner.

\section{CRITICAL THEORY}

Critical theory takes constructivism a step further in that it views past and present "Knowledge" (defined as knowledge that has been formally accepted and "canonized") as being socially constructed. Critical theory purports that knowledge (as a concept) isn't neutral [2]. It is influenced by the cultural view and experiences of the person who constructed it. Therefore one cannot possess a complete understanding of a certain piece of knowledge unless one takes into account the point of view or biases of the person who constructed it, including that individual's power, privilege, and position. While "history is always written by the victors" (Winston Churchill), in reality there may be multiple perspectives and interpretations of any given event. As critical theorists put it, there are "other ways of knowing." Critical theory can be used to articulate what students bring to the study of ethics in computing, and analysis of how what we bring to it influences what we get out of it. This is not to say everything is subjective and individual; rather critical theory tries to examine what types of questions we should pose about the topic at hand, such as, "Who stands to benefit most from certain courses of action?" 
In the classroom, carefully applied Constructivist and Critical theory approaches can provide an interpersonal context of mutual respect in which power and authority is shared between students and instructor [4]. It should be noted that these approaches are not tools, rather they are dispositions that guide how different tools, such as a case study, a group discussion or a role play, are used. As [2] has said, "You can't teach democratic values with a stick and coercion". We propose the same holds true for teaching professional ethics. As teachers we must provide opportunities for students to experience, interact, reflect and construct their internal principles and to regulate their behavior voluntarily and through their own conviction. This kind of autonomous moral character cannot be coerced.

\section{CHARACTERISTICS OF A CONSTRUCTIVIST CLASSROOM}

Some of our readers are familiar with the challenges of selecting and presenting tools such as case studies, codes of ethics, and even more formal approaches to the teaching of ethics. Others may hunger to know more about how this largely theoretical discussion may impact content and presentation of their information security ethics classes. While a comprehensive list is beyond the scope of this paper, we would like to briefly discuss characteristics of learning spaces and presentations that are constructivist or critical theory-oriented.

Constructivist classrooms are more "student-centric" than "teacher-centric" in that student voices (and not always the same ones) are heard in the task at hand almost as often as the instructor's. Whereas in the traditional classroom, the instructor's voice is predominant in imparting knowledge, in the constructivist classroom, student voices are heard in activities such as role playing, debriefing, discussions, and presentations while the instructor facilitates rather than dominates the learning activities. In the traditional classroom, all eyes and ears are on the teacher, whereas in the constructivist classroom, students more often look at and speak with one another as they engage in learning activities.

A constructivist presentation will provide experiential learning situations that will meet the students where they are and take them further down the road. Because people need actual experiences before they can construct anything out of them, it might be best to start where students are - for instance can they recognize an unethical situation in their student life - say in their use of the university's computer resources - and can they decide what to do and follow through? We might add that if students cannot recognize an unethical situation in their student life, then how can we expect them to recognize and make the correct choices in unethical situations in their work life? A constructivist approach to teaching professional ethics will provide opportunities for experience and follow up with opportunities for debriefing, interaction and reflection. Finally, a constructivist classroom requires students to produce (construct) products that reflect their individual and/or collective thinking.

One potentially interesting conundrum with using a critical theory approach to teaching ethics is that students may attempt to "deconstruct" codes of ethics as "just another" authoritative claim and/or desire to construct a different code of ethics. But we believe these may not be entirely bad. When students look critically at their own underlying assumptions as well as authoritative claims, the hope is that they will recognize and internalize universal ethical principles embodied in codes of ethics and frameworks and make these truly their own way of life. We acknowledge that there is a dilemma in deciding whether to "teach professional codes of ethical standards as a static body of knowledge (Stage 2 - following orders by the book) or to encourage students to arrive at their own decisions and codes, thereby risking disagreement with the stated code" [15]. While there is no guarantee that this will not occur, a personal theory that is well grounded in a professional code but also tested through active experimentation and concrete experience will serve students for a lifetime.

\section{CONCLUSION}

In helping students develop morally, it would seem there are no easy answers. We hope this presentation will simply encourage you to experiment and refine the ways you construct and present learning experiences in information security ethics and to continue to look to the literature for ideas and experiences of other practitioners. Moral development occurs over a life time, and unlike other learning tasks, does not neatly fit within conventional teaching time frames. In other words, we may never see the full end result of what we have started, no more than we can look to the future and know what new ethical dilemmas the cyber frontier may present to our students. The important thing is that these new challenges not slip by unnoticed and unrecognized by our young professionals and that they be prepared, as best possible, to construct and implement ethical solutions both individually and cooperatively. As we seek to develop the ethical reasoning abilities of our students, we want them to realize that there are some ethical questions that have 'right' answers and others where the best answer is not a matter of absolute 'right' and 'wrong', but a matter of discussion, reflection, reasoned debate, and or character. We believe that constructivism and critical theory approaches are particularly well suited to laying a foundation of professional ethics because they give all students a chance to exercise their "voice," and because they empower students "to know, to care, and to act."

\section{ACKNOWLEDGEMENTS}

This material is based upon work supported by the National Science Foundation under Grant No. 0113725. Any opinions, findings, and conclusions or recommendations expressed in this material are those of the author(s) and do not necessarily reflect the views of the National Science Foundation.

\section{REFERENCES}

[1] Alcorn, P. (2001). Practical ethics for a technological world. Columbus, OH: Prentice Hall.

[2] Banks, J. (1993). The canon debate, knowledge construction, and multicultural education. From The Educational Researcher. 22(5). In Haworth, J.G. \& Conrad, C.F. (Eds). (1995). Needham Hts., MA: Simon \& Schuster Custom Publishing, pp. 205-219.

[3] Bynum, T. (2001). "Computer ethics: Basic concepts and historical overview." The Stanford Encyclopedia of Philosophy (Winter 2001 Edition), Edward N. Zalta (ed.), $\mathrm{URL}=$ 
$<$ http://plato.stanford.edu/archives/win2001/entries/ethicscomputer/ $>$.

[4] DeVries, R. (1998). Implications of Piaget's constructivist theory for character education. Action in Teacher Education 20 (4), 39-47. Retrieved March 27, 2003 from Wilson (OmniFile Full Text Mega) Databases.

[5] Dick, G. (1994). "Raising the awareness of ethics in IT students: Further development of the teaching model." Ethics in the Computer Age (69-73) . Retrieved 26 February 2004 from http://portal.acm.org/browse_dl.cfm?linked=1\&part=series\&

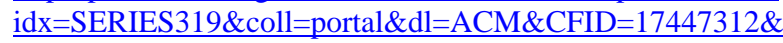
CFTOKEN=93356124.

[6] Fisher, T., \& A. Abunawass. (1994). "Computer ethics: A capstone course.” Ethics in the Computer Age (74-79) . Retrieved 26 February 2004 from http://portal.acm.org/browse_dl.cfm?linked=1\&part=series\& idx=SERIES319\&coll=portal \&dl=ACM\&CFID $=17447312 \&$ CFTOKEN=93356124.

[7] Freire, P. (1973). Pedagogy of the Oppressed, NY: Seabury

[8] Greene, J., \& Haidt, J. (2002). How (and where) does moral judgment work? Trends in Cognitive Science, 6 (12), pp. 517-523.

[9] Gronlund, N. (2003). Writing instructional objectives for teaching and assessment ( $7^{\text {th }}$ ed.). Upper Saddle River: Prentice Hall.

[10] Johnson, D. (2001). Computer ethics ( $3^{\text {rd }}$ ed.). Upper Saddle River: Prentice Hall. (Original work published 1985).
[11] Kohlberg, L., \& Kramer, R. (1969). Continuities and discontinuities in childhood and adult moral development. Human Development, 12, pp. 93-120.

[12] Luegenbiehl, H. (1992). “Computer professionals: Moral autonomy and a code of ethics.” Journal of Systems Software, 17 (61-68).

[13] Martin, D., \& Weltz, E. (1999). "From awareness to action: Integrating ethics and social responsibility into the computer science curriculum.” Computers and Society (6-14). June, 1999.

[14] Nussbaum, M. (1997). Cultivating Humanity: a classical defense of reform in liberal education, Cambridge: Harvard University Press.

[15] Pelsma, D. \& Borgers, S. (1986). Experience-based ethics: A developmental model of learning ethical reasoning. Journal of Counseling and Development, 64, 311-314.

[16] Rahanu, H. (1999). "Teaching professional and ethical aspects of computing: A case study approach.” Computers and Society, December, 1999. (32-37).

[17] Reynolds, G. (2003). Ethics in information technology. Thomson Course Technology;

[18] Smith, T., \& Ragan, P. (1999). Instructional design. Wiley.

[19] Spinello, R. (2003). Case studies in information technology ethics ( $2^{\text {nd }}$ ed.). Upper Saddle River, NJ: Prentice Hall. 